\title{
Affirmative Action: An Opinion Submitted to the Brazilian Supreme Court in the Case ADPF/186 1
}

\section{Luiz Felipe de Alencastro}

Center for Brazilian and South Atlantic Studies and Department of History University of Paris, Sorbonne

Parecer sobre_a_Arguição de Descumprimento de Preceito Fundamental, ADPF 186 (4 Mar. 2010) (apresentada ao Supremo Tribunal Federal por Luiz Felipe de Alencastro).

Translated by Arthur Brakel

In the current year of 2010, Brazilian citizens of African descent who, in the national census, have defined themselves as blacks ("pretos") and browns ("pardos") have become the country's demographic majority. From this point on, according to the criteria used to classify people according to their color-criteria that have been consolidated during decades of research and methodological analyses at the Instituto Brasileiro de Geografia e Estatística (IBGE, the Brazilian Institute of Geography and Statistics) the majority of the Brazilian population is black.

This change is much more than demographic. It tells us something of our past, of who we are and from where we came. It also constitutes a challenge for our future.

My address is an attempt at uniting both sides of this problem. It begins with a historic résumé so as to bring us up to date and to speak to the judgment at hand. Teachings from the past make us aware of how prevalent the black population was in the formation of the Brazilian people. We all know that blacks' presence in Brazil both began with violence and developed under violent conditions. Nonetheless, slavery's extent and impact have not been sufficiently highlighted. The initial petition for unconstitutionality contained in the proposal for Non-Compliance of the Fundamental Rule ADPF/186 that

1. Translated from the Portuguese by Arthur Brakel. 
the Democratas (DEM) Party presented to the Supreme Court is generically worded concerning "the racism and the option for black slavery" (pp. 37-40). It says nothing about Brazil's specific form of slavery.

In truth, no country in the Americas practiced slavery as extensively as Brazil did. Of the nearly 11,000,000 Africans who were deported and arrived alive in the Americas, $44 \%$ (nearly 5,000,000) came to Brazil during the three centuries between 1550 and 1856. The other large slave-holding country, the United States, engaged in African slave trade for a little more than one century (between 1675 and 1808) and took in a much smaller percentage of the slave traffic-around 560,000 Africans, i.e., 5.5\% of the total transatlantic slave trade. ${ }^{2}$ In the end Brazil has been the American political aggregate that captured the greatest number of Africans and that practiced slavery longer than any other country.

During those three centuries millions of Africans came to our shores. Notwithstanding their suffering and their misery, those deportees had the courage and hope to start families, and they provided cultural patterns that have formed an essential part of the Brazilian nation. As the Brazilian poet Castro Alves tells us in some of the less-remembered verses of his 1868 poem 'Navio Negreiro' (Slave Ship): the enslaved were wrenched forever from their families, their villages, and their continent. They were taken from their land by Luso-Brazilian slave purveyors and then genuine Brazilian slave traders brought them here in chains and in ships flying the yellow and green Brazilian flag.

In the $19^{\text {th }}$ Century, the Empire of Brazil was the last remaining independent nation to practice large scale Slave Trade. As the target of British diplomatic and naval pressure, the Atlantic slave trade became proscribed by a network of international treaties England had woven in the Altantic. ${ }^{3}$

The Anglo-Portuguese treaty of 1818 prohibited slave trade north of the Equator. Following the Anglo-Brazilian treaty of 1826, the (Brazilian) law of 7 November 1831 made all Atlantic slave trade illegal in Brazil.

Nonetheless, 50,000 Africans coming from the Northern Hemisphere were illegally brought to Brazil between 1818 and 1831, and 710,000 people from all parts of Africa were brought clandestinely to Brazil between 1831 and 1856. Neverthelesss, both the 1818 treaty and the 1831 law guaranteed freedom to Africans brought to Brazil after the prohibition of the slave trade. Consequent-

2. See the Slave Voyage Database: http://www.slavevoyages.org/tast/index.faces

3. In addition to is supercilious argumentation, the DEM has demonstrated its woeful ignorance of Brazilian history. In its petition the DEM (p. 35) proposes: "Why not direct to Portugal and England whatever indemnification is due the descendants of Africans since the Portuguese and the English organized the slave trade and slavery in Brazil?” As is well-known, the English had no role in Brazilian slavery, since the slave trade was a Portuguese monopoly, albeit with active Brazilian participation in the $19^{\text {th }}$ century. Quite to the contrary, and for reasons beyond the purpose of this text, England played a decisive part in the extinction of the black slave traffic to Brazil. 
ly, the alleged owners of these free people were considered kidnappers and were subject to sanctions according to Article 179 of the 1830 Criminal Code, which punished the act of "enslaving free people." In 1831 the $7^{\text {th }}$ of November Law imposed a fine on these lawbreakers and made them pay for sending kidnapped Africans back-to any African port. These penalties appear again in Article 4 of the $4^{\text {th }}$ of September Law (1850), i.e. the Eusébio de Queirós Law that definitively ended our transatlantic slave trade.

However, during the 1850s, the Empire regularly granted amnesty to slaveholders guilty of kidnapping, and it allowed the correlated crime of enslaving free people to go on. ${ }^{4}$ Indeed, the 760,000 Africans brought to Brazil up to 1856, as well as all their descendants, went on as slaves until $1888 .{ }^{5}$ It was necessary to enact an over-arching collusion, a pact favoring the violation of anti-slavery laws so as to avoid slave rebellions, as well as rebellions of people who were illegally enslaved. This collusion ensured that slave owners, i.e. kidnappers, as well as their partners and creditors need not be overly concerned that the country might collapse. This pact, in the words of Minister of Justice Nabuco de Araújo, was founded on the "collective interest of [Brazilian] society."

This subject underlies many debates during those years. Nabujo de Araújo's son, Joaquim Nabuco, who is being celebrated this year, the centenary of his death, had this to say in Abolicionismo (1883): "For 50 years the greater part of slaves was held illegally. Collectively, nothing could be more difficult for the slaveholders than to justify before a scrupulous court of law the legality of their slave possessions, taken also as a whole."

There was never any 'scrupulous court of law' in the judicial system of the time, nor can one be found in Brazilian historiography. Aside from the lawsuits pleaded by a few abolitionist lawyers and magistrates, this matter was covered up at that time and was practically ignored by subsequent generations.

It turns out that this collective crime has a dramatic meaning: in spite of the laws, the majority of Africans brought to Brazil after 1818 (as well as all their descendants) were held in slavery until 1888. That is, the majority of the

4. A. Perdigão Malheiro. A Escravidão no Brasil-Ensaio Histórico, Jurídico, Social (Petrópolis, RJ, Brasil: Vozes, 1976), 1:201-222.

5. Beatriz G. Mamigonian in a paper given at the Centre d'Études du Brésil et de l'Atlanique Sud. (University of Paris, Sorbonne, 21 November 2006). D. Eltis. Economic Growth and the Ending of the Transatlantic Slave Trade (Oxford: OUP, 1989), A:234-244.

6. This quote comes from a confidential message to the President of São Paulo Province in 1854. The minister invoked "the collective interests of [Brazilian] society" as a justification for not enforcing the 1831 law that provided freedom for Africans brought to Brazil after that date. Joaquim Nabuco. Um Estadista do Império (1897-1898) (Rio: Topbooks, 1997), 1:229, n. 6.

7. Joaquim Nabuco. O Abolicionismo (Petrópolis, RJ, Brazil: Vozes, 1977), 115-120, 189. Fifteen years later, confirming the primordial importance of the African slave trade, as well as the non-Brazilian source of slaves, Nabuco maintained that it was easier for Brazilians to abolish slavery in 1888 than it was to obey the 1831 law. Um Estadista do Império (1897-1898) (Rio: Topbooks, 1997), 1:228. 
last two generations of enslaved people in Brazil were not slaves. Slavery is morally illegitimate, and, beyond this, Brazilian slavery was first and foremost illegal. As I have written, and as far as I am concerned, the kidnappers' pact constitutes our society's and our legal system's original $\sin ^{8}$

We established a long-lasting principle of impunity and casuistry in the law that brands our history and that is still a constant challenge to our courts and to this Supreme Court.

Another perversion generated by the "evils slavery created," to use another of Joaquim Nabuco's expressions, is related to police violence. In my exploration of this matter, I ask permission to return to the $19^{\text {th }}$ Century so as to remind the members of this Court of an issue in the history of criminal law with which they are all familiar.

After independence, in both Brazil and the United States, slavery became an integral part of the State Building, i.e. of the organization of the nation's institutions. Slavery became "modernized" so as to harmonize it with positive laws and with the new Western norms that regulated private property and public liberty. Among the manifold contradictions this situation engendered, one stands out in the Criminal Code: how to punish law-breaking slaves without putting them in prison? How to do this without depriving their owners of the rewards of their slaves' labor if their slaves were sentenced to prison?

To solve this problem, the legal framework was divided into two phases. In the first case, the 1824 Constitution guaranteed, in Article 179, an end to the constant corporal punishment as in the Portuguese criminal procedures. "From this point on, whippings, torture, branding, and all other cruel punishments are abolished." The Constitution also prescribed the following: "prisons and jails will be safe, sanitary, and ventilated, [and] there will be different buildings to house inmates according to the circumstances and the nature of their crimes."

In accord with the principles of the Enlightenment, the liberty and dignity of free men were thus preserved.

In the second phase, the 1830 Criminal Code dealt specifically with the imprisonment of slaves, who made up a large proportion of the Empire's population. In Article 60, the Code reintroduced torture. "If the prisoner be a slave and not sentenced to death or to the galleys, he will be condemned to whipping, and after that, he shall be returned to his owner, who will be obliged to keep him in chains to the extent and the time that said judge indicates, the number of whiplashes will be set at sentencing, and the slave will suffer no more than 50 per day." By whipping and torturing, one could punish without incarcerating - the dilemma was solved.

Far from being a strictly rural phenomenon, slavery was also a fact of life in

8. L.F. de Alencastro, "A desmemória e o recalque do crime na política brasileira," in Adauto Novaes, O Esquecimento da Política (Rio de Janeiro: Agir, 2007), 321-334. 
the cities. In 1850 Rio de Janeiro counted 110,000 slaves among its 266,000 inhabitants. This was the largest urban concentration of slaves in modern times. Within this social framework the matter of public safety and criminality assumed a specific bias. ${ }^{9}$ Even more efficacious than imprisonment, the National State employed terror and the threat of public whippings to intimidate slaves.

As an official punishment, this practice went on until the end of Slavery (1888) and was applied to society's less favored members, to blacks in particular and to the poor in general. Along with the privatization of justice, e.g. when the rural slave holders took matters into their own hands, this modus operandi precluded the advent of a public safety policy founded on the principles of individual freedom and human rights.

And finally, a third perversion created by slavery directly affects the statute of citizenship.

We know that, up to the promulgation of the 1881 Saraiva Law, in the Empire's two-degree electoral censuses, illiterates, including freed blacks and mulattoes could vote. That is, they could be $1^{\text {st }}$ degree voters who elected $2^{\text {nd }}$ degree voters (around 20,000 men in 1870), and the latter voters could elect, or be elected, members of parliament. After 1881, the system using two degrees of voters was abandoned, and the following year (1882) illiterates could no longer vote. As a measure taken in pre-abolitionist circumstances, this restriction sought to create a safety lock that would keep freedmen from voting. This created a statute of infra-citizenship that lasted until 1985, when illiterates were once more allowed to vote. The entirety of Brazilian illiterates, white and black, suffered from this law. ${ }^{10}$ But the political exclusion it caused had a greater impact on the black population, in which illiteracy had, and continues to have, proportionally higher indices than it does among whites. ${ }^{11}$

Thanks to the data mentioned above, the lessons from our past help us situate the current judgment on university entrance quotas. We can examine it in the perspective of nation building and our country's political system. With its origin in the $19^{\text {th }}$ Century, beginning with the impunity guaranteed to slave-

9. Luiz Felipe de Alencastro, "Protelários e Ecravos: imigrantes portugueses e cativos africanos no Rio de Janeiro 1850-1870," in Novos Estudos Cerbrap, (São Paulo: Cerbrap, 1988), 21: $30-56$.

10. Elza Berquó and L.F. de Alencastro, "A emergência do voto negro," in Novos Estudos Cerbrap (São Paulo: Cerbrap, 1992), 33:77-88.

11. The 1980 census shows that the proportion of people older than 5 years of age who "had no schooling or less than a year of instruction" was $47.30 \%$ among blacks, $47.60 \%$ among racially mixed people, and $25.10 \%$ among whites. This disproportion was soon reduced, but it has not changed in the last 20 years. According to The National Surveys of Sample Households (PNADS), in 1992, among Brazilians over 15 years of age, illiterate whites represented $4.00 \%$, and blacks $6.10 \%$. In 2008 these percentages rose to $6.50 \%$ and $8.30 \%$ respectively. The greater percentages of illiterates come, largely, from the fact that beginning in 2004, PNADS started counting the rural population in Rondônia, Acre, Amazonas, Roraima, Pará, and Amapá (data taken from the Institute of Applied Economic Research, or IPEA). 
holders whose "property" had been illegally enslaved, the high-handedness slavery engendered has submerged the entire country.

However, if we act to counter this dynamic and reduce the discrimination that still weighs heavy on Afro-Brazilians, who today constitute the majority of our population, we can consolidate our democracy.

Thus, this is not simply a matter of reparations destined to settle historical debts and to guarantee the rights that were usurped from a specific community-as was largely the case in this Supreme Court's rulings on the demarcation of Native people's territories. The present case deals, above all, with setting forth a discussion on affirmative action, which will work to perfect democracy in our country's future. This is how racial quotas at our universities challenge our present and our future.

By attacking university quotas, the DEM's proposal (ADPF) has as its $3^{\text {rd }}$ point (pp. 41-43) the following caption: "The danger of importing models: the examples of Rwanda and The United States of America." The first comparison is absurd, the second is inept.

What could possibly be the parallel between Brazil and Rwanda? Rwanda only became independent in 1962, and, beginning in 1990, became involved in an over-arching conflagration that specialists now refer to as "the first African world war." This war implicated Burundi, Uganda, Angola, Congo Kinshasa, and Zimbabwe. And it culminated in 1994 with the genocide of nearly 1 million Tutsis and thousands of Rwandan Hutus.

In its comparison with the United States, the DEM's allegation is inept on two accounts. In the $1^{\text {st }}$ place, the United States is the world's oldest democracy and has provided the models for many institutions that have consolidated the political system in Brazil. Our federalism, our Federal Supreme Court, i.e. Your Federal Supreme Court, are cast in the American model. There is nothing "dangerous" in the importation of American practices that can strengthen our democracy. The second feature of their ineptitude comes from the fact that the black movement and the defense of the civil rights of ex-slaves and people of African descent is, as I said above, deeply rooted in Brazil's history. Beginning in the $19^{\text {th }}$ Century, black and white magistrates and lawyers have played a fundamental role in righting these wrongs. ${ }^{12}$

12. Thus, in 1880, when the abolitionist campaign took root with the foundation of the Brazilian Abolitionist Society, the black jurist José do Patrocínio set forth in Rio de Janeiro's Gazeta de Notícias, the matter of indemnification for victims of slaveholders' non-compliance with the 1831 law. José do Patrocínio made his calculations based on the statistics available at the time. He took the number of Africans brought to Brazil between 1831 and 1856, estimated the total number of their descendants, added up the years and days they worked, and multiplied those years and days by $200-200$ reis was a day's salary at that time. This was the first time in Brazil that anyone proposed and calculated the amount of indemnification owed to the victims of the criminal slave trade. Be aware that this was not an effort to make amends or to free the people who were still slaves in Brazil. It actually proposed a liquid and exact amount owed to free people 
Consequently, and contrary to what has been said and written, rather than being an "Americanization" of the debate on racial discrimination in Brazil, the discussion we took up once more during the 1970s and 1980s concerning racial inequality is much more the result of updating Brazilian social statistics in the context of democratic struggles against the dictatorship. On top of this, these very circumstances at the very same time occasioned the inquiries on income distribution within the framework of the alleged "economic miracle." Up until 1976 and the first National Survey of Sample Households (PNAD), which registered people's color, there was next to nothing known about Afro-Brazilians' social and demographic evolution.

Indeed, in the 1950 census statistics related to color were limited. In the 1960 census they were useless. And in the 1970 census they were not taken into account. This long period of statistical eclipse facilitated the spread of the "Brazilian racial democracy" ideology, which promoted the notion that there was no racial discrimination in the country. However, the household samplings of 1976, 1984, 1987, 1995, 1999 and the censuses of 1980, 1991, and 2000 included skin color among their criteria. It was shown that in the course of three decades, racial inequality persisted even in the framework of a more urbanized, better educated, and wealthier society than what was the case in 1940 or 1950. Put another way, the data proved that racial inequality was of a structural nature and had not been attenuated notwithstanding the country's social and economic progress. And this is the basis for the increasing claims made by our black community and supported by several political parties and by a large number of social movements.

In this vein it is worth remembering that, as a response to our society's aspirations, and to pioneering countries' initiatives, democracy, democratic activity, is a dynamic process that has been reformed and fleshed out by Brazilian legislators over the decades. It was only in 1932, and at that time with wellknown restrictions that were abandoned in 1946, that women were allowed to vote in Brazil. At that time traditionalists alleged that women's suffrage would break up families and upset the nation's social peace. Little by little, consensual norms that had hindered women's full citizenship and professional achievement were attenuated according to the rule that can also be applied in racial matters-we should deal in unequal ways to solve the problem generated by an unequal status.

As I see it, beyond the matter at hand, i.e. the racial quota policy for the University of Brasília, this judgment will address two essential issues.

This is the first issue: In spite of there being no legal basis for racial discrimination, does the Afro-Brazilian population suffer from discrimination today?

who had been kidnapped and enslaved by their alleged owners thanks to the government's and the imperial courts" complicity. L.F. de Alencastro, "A desmemória e o recalque do crime na política brasileira," op. cit. 
We can find the answer in our day care centers, on our streets, in our schools, in our universities, in our jails, and in the verdicts of Medical Legal Institutes throughout Brazil. This is not the place for me to start analyzing racial, social, and economic statistics. These will be dealt with by different specialists during this Public Hearing. I shall point out, however, that in the Matter of Non-Compliance of the Fundamental Rule that the DEM has presented, the part titled "The manipulation of social indicators involving race" (pp. 54-59) puts forth some data and cites as its sole analytic source the journalist Ali Kamel's book. Kamel, as everyone knows, is not familiar with the statistics coming from the Brazilian Institute of Geography and Statistics (IBGE), nor with those from the Institute of Applied Economic Research (IPEA), nor with any from the United Nations, much less from the innumerable Brazilian and Foreign research projects and theses that offer massive proof of racial prejudice's existence in Brazil.

From these statistics comes the second issue that we can formulate succinctly. Has the social advancement system put in place after Abolition been able to eliminate the inequities that surround the Afro-Brazilian population? Will the expansion of quotas and scholarships based on social criteria bring about a reduction of those inequities?

The data the IPEA has assembled from the National Survey of Sample Households demonstrate that, quite to the contrary, these inequities have persisted throughout the last decade. And beyond this, admissions to institutes of higher education have exacerbated racial inequality in Brazil.

In primary education (for students between the ages of 7 and 14), the difference between percentages of white and black children attending school started falling beginning in 1999. By 2008 the two groups' rate of attendance was practically the same, around $95 \%$ and $94 \%$ respectively. In secondary education (ages 15 to 17) we see an almost constant difference between the years of 1992 and 2008. In $200861.00 \%$ of white children and $42.00 \%$ of black children in this age group were in school. However, in higher education the difference between the two groups widens. In 2008, among whites older than 18, 20.50\% attended college. Among blacks of the same age only $7.70 \%$ attended college. ${ }^{13}$ It is obvious that access to higher education is an unavoidable bottleneck in the social advancement of Brazilian blacks.

For these reasons I reaffirm my support of racial quotas at the University of Brasília.

I consider it simplistic to see the debate on racial quotas as a split between right and left, between the government and the opposition, or between the Partido dos Trabalhadores (Workers' Party, or PT) and the Partido Social Democrata Brasileiro (Brazilian Social Democratic Party, or PSDB). As in the

13. These data come from Mário Lisboa Theodoro, an IPEA researcher who is also a presenter at this Public Hearing. 
case of the 1993 national plebiscite on presidentialism vs. parliamentarianism, the split crosses party and ideological lines. On top of this, the first affirmative action measures concerning our black population were taken, as is well known, during the administration of Fernando Henrique Cardoso (1995-2002).

As I have made clear, I have based my arguments on several studies carried out by the Institute of Applied Economic Research. Indeed, both Professor Roberto Borges Martins, the Institute's president during the second Cardoso administration, and Professor Márcio Porchman, its president during the second Lula administration, who are two colleagues I admire and respect, have coordinated several contemporary studies on racial discrimination in Brazil. And both of them are in favor of affirmative action and racial quotas in university admissions.

The existence of inter-ideology alliances should lead us, even in an election year, to a less ideological debate in which arguments from different points of view can be analyzed so as to contribute further to overcoming the racial inequities that weigh on the Brazilian blacks and on Brazilian democracy. 